\title{
Effective densities of soot particles and their relationships with the mixing state at an urban site in the Beijing megacity in the winter of 2018
}

\author{
Hang Liu ${ }^{1,2}$, Xiaole Pan ${ }^{1}$, Yu Wu ${ }^{3}$, Dawei Wang ${ }^{1}$, Yu Tian ${ }^{1,2}$, Xiaoyong Liu ${ }^{1,4}$, Lu Lei ${ }^{1,2}$, Yele Sun ${ }^{1,2,4}$, Pingqing Fu ${ }^{5}$, \\ and Zifa Wang ${ }^{1,2,4}$ \\ ${ }^{1}$ State Key Laboratory of Atmospheric Boundary Layer Physics and Atmospheric Chemistry, Institute of Atmospheric \\ Physics, Chinese Academy of Sciences, Beijing, 100029, China \\ ${ }^{2}$ University of Chinese Academy of Sciences, Beijing, 100049, China \\ ${ }^{3}$ State Key Laboratory of Remote Sensing Science, Institute of Remote Sensing and Digital Earth, Chinese Academy of \\ Sciences, No. 20 Datun Road, Beijing, 100101, China \\ ${ }^{4}$ Center for Excellence in Regional Atmospheric Environment, Chinese Academy of Science, Xiamen, 361021, China \\ ${ }^{5}$ Institute of Surface-Earth System Science, Tianjin University, Tianjin, 300072, China
}

Correspondence: Xiaole Pan (panxiaole@ mail.iap.ac.cn)

Received: 3 June 2019 - Discussion started: 29 July 2019

Revised: 25 October 2019 - Accepted: 2 November 2019 - Published: 9 December 2019

\begin{abstract}
The effective density ( $\rho_{\text {eff }}$ ) of refractory black carbon $(\mathrm{rBC})$ is a key parameter relevant to its mixing state that imposes great uncertainty in evaluating the direct radiation forcing effect. In this study, a tandem differential mobility analyzer-centrifugal particle analyzer-single-particle soot photometer (DMA-CPMA-SP2) system was used to investigate the relationship between the effective density $\left(\rho_{\text {eff }}\right)$ and the mixing state of $\mathrm{rBC}$ particles during the winter of 2018 in the Beijing megacity. During the experiment, aerosols with a known mobility diameter $\left(D_{\mathrm{mob}}\right)$ and known $\rho_{\text {eff }}$ values $\left(0.8,1.0,1.2,1.4,1.6\right.$, and $\left.1.8 \mathrm{~g} \mathrm{~cm}^{-3}\right)$ were precisely selected and measured by the SP2 to obtain their corresponding mixing states. The results showed that the $\rho_{\text {eff }}$ well represented the morphological variation in $\mathrm{rBC}$-containing particles. The $\mathrm{rBC}$-containing particles changed from an irregular structure to a compact spherical structure with the increase in $\rho_{\text {eff }}$. A $\rho_{\text {eff }}$ value of $1.4 \mathrm{~g} \mathrm{~cm}^{-3}$ was the morphological transition point. The morphology and $\rho_{\text {eff }}$ value of the $\mathrm{rBC}$-containing particles were intrinsically related to the mass ratio of non-refractory matter to $\operatorname{rBC}\left(M_{\mathrm{R}}\right)$. As the $\rho_{\text {eff }}$ values of the $\mathrm{rBC}$-containing particles increased from 0.8 to $1.8 \mathrm{~g} \mathrm{~cm}^{-3}$, the $M_{\mathrm{R}}$ of the $\mathrm{rBC}$-containing particles significantly increased from 2 up to $6-8$, indicating that atmospheric aging processes were likely to lead to the reconstruction of more compact and regular particle shapes. During the
\end{abstract}

observation period, the $\rho_{\text {eff }}$ of the majority of rBC-containing particles was smaller than the morphology transition point independent of the pollution conditions. This suggested that the major $\mathrm{rBC}$-containing particles did not have a spherical structure. Simulation based on an aggregate model considering the morphological information of the particles demonstrated that absorption enhancement of rBC-containing particles could be overestimated by $\sim 17 \%$ by using a core-shell model. This study highlights the strong dependence of the morphology of ambient $\mathrm{rBC}$-containing particles on $\rho_{\text {eff }}$ and will be helpful for elucidating the microphysical characteristics of $\mathrm{rBC}$ and reducing uncertainty in the evaluation of $\mathrm{rBC}$ climate effects and health risks.

\section{Introduction}

Refractory black carbon (rBC) is the major light-absorbing aerosol in the atmosphere. It plays a vital role in the climate by influencing the radiative balance, cloud properties, and glaciers (Flanner et al., 2007; Ramanathan and Carmichael, 2008; Bond et al., 2013). rBC is considered to be one of the most important global warming factors (Bond et al., 2013). Additionally, as a component of $\mathrm{PM}_{2.5}$ (particulate matter with an aerodynamic diameter less than $2.5 \mu \mathrm{m}), \mathrm{rBC}$ has 
an adverse environmental effect because it degrades visibility and harms the human respiratory system (Apte et al., 2015; Lelieveld et al., 2015; Raaschou-Nielsen et al., 2013; Dominguez-Rodriguez et al., 2015). The control of rBC emission is an immediate and win-win strategy to face climate and environmental challenges.

In the troposphere, rBC mixes with other components, such as organics, sulfate, and nitrate, through condensation, coagulation, heterogenous chemistry, or other complicated processes. Many studies have reported that the mixing state of $\mathrm{rBC}$-containing particles greatly impacts the absorption ability (Shiraiwa et al., 2008; Nakayama et al., 2010; Shiraiwa et al., 2010) and hygroscopicity of $\mathrm{rBC}$ (Zhang et al., 2008; Moteki et al., 2012; Liu et al., 2013) based on a combination of laboratory, numerical model, and field measurement methods. However, debate exists among researchers. For instance, several studies (Lack et al., 2012; Wang et al., 2014, 2016; Wu et al., 2016) observed a large absorption enhancement of $\mathrm{rBC}$ caused by mixing with the coating material, whereas other studies found negligible absorption enhancement (Cappa et al., 2012; Lan et al., 2013). Liu et al. (2017) proposed that the mixing structure of rBCcontaining particles depended on the proportion of coating material. When coating materials are insufficient to encapsulate $\mathrm{rBC}$, they tend to attach to it and provide little absorption enhancement. Sufficient coating materials will change rBCcontaining particles to a core-shell structure and significantly contribute to light absorption. Thus, the morphology of rBCcontaining particles needs to be further studied to minimize the error in the estimation of rBC's absorption enhancement effect. Moreover, the morphology of rBC-containing particles causes uncertainty in evaluation of the dose deposited in the respiratory system and thus in health risk estimations (Londahl et al., 2008; Alfoldy et al., 2009).

Laboratory inspection using transmission electron microscopy (TEM) can provide visual evidence of and information on the morphology of rBC-containing particles (China et al., 2013; Adachi and Buseck, 2013; Adachi et al., 2010). The common opinion based on TEM results is that bare rBCcontaining particles adopt a fractal chain-like structure that will become more compact during the aging process (Wang et al., 2017). However, the representativeness of the TEM results remains a question. Since identifying $\mathrm{rBC}$-containing particles using TEM is time-consuming work, the number of rBC-containing particles observed in one TEM study often ranges between hundreds and thousands, which is a tiny fraction of the ambient $\mathrm{rBC}$-containing particles. Another way to determine the morphology of $\mathrm{rBC}$-containing particles is to measure a physical index, such as the effective density ( $\left.\rho_{\text {eff }}\right)$, shape factor $(\chi)$, fractal dimension, etc. For instance, the $\rho_{\text {eff }}$ is defined as the ratio of the particle mass $\left(M_{\mathrm{p}}\right)$ to the volume of its mobility-equivalent sphere. The compactness of a particle can be determined by comparing the $\rho_{\text {eff }}$ with the material density (the density of particles with a solid spheri- cal structure). For particles with the same material density, a smaller $\rho_{\text {eff }}$ indicates a looser structure.

In practice, a differential mobility analyzer (DMA), aerosol particle mass (APM) analyzer (or a centrifugal particle analyzer, CPMA), and condensation particle counter (CPC) are often integrated to obtain the $M_{\mathrm{p}}$ and mobility diameter $\left(D_{\text {mob }}\right)$ simultaneously. Then, the $\rho_{\text {eff }}$ is calculated by Eq. (1):

$\rho_{\mathrm{eff}}=\frac{6 M_{\mathrm{p}}}{\pi D_{\mathrm{mob}}^{3}}$.

The $\rho_{\text {eff }}$ is often used in laboratory studies to determine the morphology of rBC (Xue et al., 2009; Pagels et al., 2009; Zhang et al., 2008). The freshly emitted rBC-containing particles are characterized by a significantly lower $\rho_{\text {eff }}$ than the $\mathrm{rBC}$ material density of $1.8 \mathrm{~g} \mathrm{~cm}^{-3}$ suggested by Bond et al. (2013). Zhang et al. (2008) observed that the $\rho_{\text {eff }}$ of rBCcontaining particles changed from 0.56 to $1.60 \mathrm{~g} \mathrm{~cm}^{-3}$ after $\mathrm{H}_{2} \mathrm{SO}_{4}$ condensation, indicating reconstruction of $\mathrm{rBC}$ during the condensation process, which was consistent with the TEM results. Further studies showed that BC reconstruction was caused by the surface tension of the coating material, which differed for various coating compositions (Xue et al., 2009; Pagels et al., 2009).

In the laboratory, a high concentration of rBC-containing particles is normally generated by a laminar diffusion burner, and the $\rho_{\text {eff }}$ of $\mathrm{rBC}$-containing particles can be reasonably studied using the DMA-CPMA-CPC system. Investigation of the $\rho_{\text {eff }}$ of rBC-containing particles using a DMACPMA-CPC tandem system would be difficult because there are substantial non-rBC particles in the ambient atmosphere. The $\rho_{\text {eff }}$ determined using this approach is only representative of the characteristic of the bulk aerosols and not the rBC-containing particles. A single-particle soot photometer (SP2) is able to distinguish rBC-containing particles from non-rBC particles at a single-particle resolution. In this study, the CPC in the regular tandem DMA-CPMA-CPC system was replaced with the SP2, and the $\rho_{\text {eff }}$ of the rBC-containing particles and the non-rBC particles was detected separately. Additionally, the key parameters related to the $\mathrm{rBC}$ mixing state, such as the mass of the $\mathrm{rBC}$ core, number fraction of rBC-containing particles, and optical diameter of the rBCcontaining particles, were well determined through SP2 measurement. Thus, the mixing state and $\rho_{\text {eff }}$ of $\mathrm{rBC}$-containing particles were obtained simultaneously using the novel tandem DMA-CPMA-SP2 system.

In this study, field measurement using a tandem DMACPMA-SP2 system was performed from 20 December 2018 to 4 January 2019 in the urban areas of Beijing to investigate the $\rho_{\text {eff }}$ of ambient rBC-containing particles. The site is located in the tower campus of the State Key Laboratory of Atmospheric Boundary Layer Physics and Atmospheric Chemistry, Institute of Atmospheric Physics (LAPC, longitude: $116.37^{\circ} \mathrm{E}$; latitude: $39.97^{\circ} \mathrm{N}$ ). A more detailed description of the site can be found in the literature (Sun et al., 2016; 
Table 1. Abbreviations and symbols used in this paper.

\begin{tabular}{|c|c|}
\hline Abbreviation/symbols & Full name/explanation \\
\hline$\rho_{\text {non-rBC }} \& \rho_{\text {non-rBC }}$ & Effective density of non-rBC particles (rBC-containing particles) \\
\hline$\rho_{\text {non-rBC,bulk }} \& \rho_{\mathrm{rBC}, \text { bulk }}$ & $\begin{array}{l}\text { Effective density of bulk non-rBC particles (rBC-containing particles) using the weighted-average } \\
\text { method. } \rho_{\text {non-rBC,bulk }} \text { is different from } \rho_{\text {non-rBC }} \text { since the number distribution of non-rBC particles } \\
\text { with different } \rho_{\text {non-rBC }} \text { values is considered to reflect the effective density of bulk non-rBC. }\end{array}$ \\
\hline SP2 & Single-particle soot photometer (DMT) \\
\hline DMA & Differential mobility analyzer (TSI Inc.) \\
\hline CPMA & Couette centrifugal particle mass analyzer (Cambustion Ltd.) \\
\hline $\mathrm{CPC}$ & Condensation particle counter (TSI Inc.) \\
\hline $\mathrm{rBC}$ & Refractory black carbon determined by the SP2 through the laser-induced incandescence method \\
\hline$D_{\text {mob }}$ & Mobility diameter selected by the DMA \\
\hline$D_{\text {opt }}$ & Optical diameter derived from the SP2 scattering signal \\
\hline$\chi$ & Dynamic shape factor of particles representing the particle regularity \\
\hline$R_{\text {void }}$ & Void volume ratio in a particle representing the particle compactness \\
\hline$M_{\mathrm{R}}$ & The mass ratio of coatings to the $\mathrm{rBC}$ core representing the coating thickness \\
\hline $\mathrm{S} / \mathrm{C}$ ratio & $\begin{array}{l}\text { The ratio of the diameter of } \mathrm{rBC} \text {-containing particles to the diameter of the rBC core representing the } \\
\text { coating thickness }\end{array}$ \\
\hline$\sigma_{\mathrm{SC}}$ & Scattering cross section of rBC-containing particles \\
\hline MAC & Mass absorption cross section of $\mathrm{rBC}$-containing particles \\
\hline
\end{tabular}

Pan et al., 2019). Particles with different effective densities preselected by the DMA-CPMA were injected into the SP2. A comprehensive analysis was conducted with a focus on the relationship between the $\mathrm{rBC}$-containing particle $\rho_{\text {eff }}$ and the mixing state. To the best of our knowledge, this study is the first report of the $\rho_{\text {eff }}$ of ambient $\mathrm{rBC}$-containing particles. This study will help elucidate the microphysical properties of $\mathrm{rBC}$-containing particles, which can reduce uncertainty in climate and health risk effect estimations.

\section{Methods}

\subsection{Single-particle soot photometer}

The detailed principle of the SP2 (Droplet Measurement Technology Inc., Boulder, CO, USA) has been reported in the literature (Shiraiwa et al., 2008; Moteki and Kondo, 2007). Briefly, due to the unique absorption ability of $\mathrm{rBC}$, each single rBC-containing particle will absorb the high-intensity laser (1064 nm, TEM00 mode) produced by the SP2. Then, the $\mathrm{rBC}$ is heated to the boiling point and emits incandescence. The peak incandescence intensity is nearly linearly correlated with the rBC mass. By detecting the incandescence, the $\mathrm{rBC}$ mass in each $\mathrm{rBC}$-containing particle can be determined. The scattering signal of each particle is obtained simultaneously by the SP2. Particles that only have a scattering signal are identified as non-rBC particles, whereas particles with concurrence of incandescence and a scattering signal are identified as $\mathrm{rBC}$-containing particles.

The SP2 was calibrated using Aquadag aerosols (lot 9627) and a polystyrene latex sphere (PSL, Nanosphere Size Standards, Duke Scientific Corp., USA) with sizes of $203 \mathrm{~nm}$ (lot
185856), $303 \mathrm{~nm}$ (lot 189903), and $400 \mathrm{~nm}$ (lot 189904). Because the SP2 is more sensitive to Aquadag than ambient rBC (Laborde et al., 2013), the incandescent signal was corrected by scaling a factor of 0.75 in the ambient measurement. The total uncertainty of the rBC mass measured by the SP2 was estimated to be $30 \%$.

\subsection{Tandem system}

The tandem system in this study included a DMA (model 3085A, TSI Inc., USA), CPMA (Cambustion Ltd.), condensation particle counter (CPC, model 3775, TSI Inc., USA), and SP2. A schematic diagram of the measurement system is provided in Fig. S1.

The CPMA was used to select particles with a known mass based on a specific charge-to-mass ratio by imposing opposite centrifugal and electric forces on the charged aerosols inside (Olfert and Collings, 2005). The DMA was used to select particles with a known mobility diameter $\left(D_{\text {mob }}\right)$ based on the particles' electromobility. The tandem DMA-CPMA system was capable of selecting particles with a known $\rho_{\text {eff }}$. The reliability of the DMA-CPMA tandem system was tested using PSL particles $\left(\rho_{\text {eff }}: 1.05 \mathrm{~g} \mathrm{~cm}^{-3}\right)$. In general, the tandem system overestimated the $\rho_{\text {eff }}$ by $5 \%$ with a mode $\rho_{\text {eff }}$ value of $1.10 \mathrm{~g} \mathrm{~cm}^{-3}$, as shown in Fig. S2. The multiple charged influences (Fig. S2) were negligible.

Particles with known effective densities preselected by the DMA-CPMA system were injected into the SP2 to obtain information on the corresponding $\mathrm{rBC}$. In practice, the mobility diameter selected by the DMA was set at a constant value of $240 \mathrm{~nm}$. The set points of the CPMA were 5.79, $7.24,8.69,10.13,11.58$, and $13.03 \mathrm{fg}$, which corresponded to a $\rho_{\text {eff }}$ of $0.8,1.0,1.2,1.4,1.6$, and $1.8 \mathrm{~g} \mathrm{~cm}^{-3}$, respec- 
tively. Each CPMA set point was held for $10 \mathrm{~min}$, and the duration of a whole scan turn of the six set points was $1 \mathrm{~h}$. In this study, the sum of particle numbers over 10 min was used to present the temporal variation in particles with different $\rho_{\text {eff }}$ values.

\subsection{Data analysis}

\subsubsection{Determination of the bulk effective density}

The number concentration of particles with six different tar-

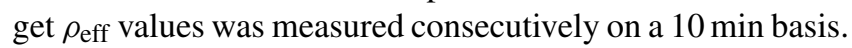
Thus, a distribution of different effective densities could be obtained every hour. Previous studies (Qiao et al., 2018; Momenimovahed and Olfert, 2015) often used a lognormal or Gaussian function to fit the $\rho_{\text {eff }}$ distribution. The $\rho_{\text {eff }}$ of the bulk aerosols was determined to be the peak location of the fit function. Due to the limited $\rho_{\text {eff }}$ measurement points in this study, the bulk aerosol density was calculated using a simple method as shown in Eq. (2). $\rho_{i}$ denotes the $\rho_{\text {eff }}$ with the maximum particle number in $1 \mathrm{~h}$, and $N_{i}$ denotes the number of particles with $\rho_{i}, \rho_{i-1}$ and $\rho_{i+1}$ denote the adjacent effective density set points of $\rho_{i}$.

$\rho_{\text {bulk }}=\frac{\rho_{i} \times N_{i}+\rho_{i-1} \times N_{i-1}+\rho_{i+1} \times N_{i+1}}{N_{i}+N_{i-1}+N_{i+1}}$

We tested this method to calculate the $\rho_{\text {eff }}$ of PSL, as shown in Fig. S3. The $\rho_{\text {eff }}$ determined using this approach was $1.09 \mathrm{~g} \mathrm{~cm}^{-3}$, which was very close to the given density of $1.05 \mathrm{~g} \mathrm{~cm}^{-3}$.

\subsubsection{Determination of the optical diameter}

For non-rBC particles, the scattering cross sections are proportional to the peak scattering intensity measured by the $\mathrm{SP} 2$. The optical diameter $\left(D_{\mathrm{opt}}\right)$ was calculated through the Mie theory with a refractive index of 1.48 and an assumption of a spherical structure. Since rBC-containing particles evaporate in the laser beam, leading to a decrease in the scattering cross section, a leading-edge-only (LEO) fit (Gao et al., 2007; Liu et al., 2014; Pan et al., 2017) method was used to retrieve the undisturbed peak scattering intensity. By assuming a core-shell structure and using the refractive indices determined by Taylor et al. (2015), 1.48 for coating and 2.26$1.26 i$ for the rBC core, the $D_{\text {opt }}$ of the rBC-containing particles can also be calculated based on the Mie scattering theory.

\subsubsection{Determination of the shape factor and void fraction}

The shape factor $\chi$ is an applicable parameter describing irregularity of a particle. When $\chi$ is equal to 1 , the particle is in a regular spherical structure, whereas a larger $\chi$ indicates that the particle is more irregular. The $\chi$ of the rBC-containing particles was calculated using the following equation (Zhang et al., 2016) in this study:

$\chi=\frac{D_{\mathrm{mob}} \times C_{\mathrm{C}}\left(D_{\mathrm{mev}}\right)}{D_{\mathrm{mev}} \times C_{\mathrm{C}}\left(D_{\mathrm{mob}}\right)}$,

where $D_{\text {mob }}$ is the mobility diameter, $D_{\text {mev }}$ is the mass equivalent diameter, and $C_{\mathrm{C}}$ is the Cunningham slip correction factor (Decarlo et al., 2004).

The void volume ratio $\left(R_{\text {void }}\right)$ was also used to represent the compactness of rBC-containing particles in this study. The $R_{\text {void }}$ is 0 for particles with an ideal solid sphere and increases when the structure loosens. The $R_{\text {void }}$ is calculated by Eq. (4):

$R_{\mathrm{void}}=1-\frac{D_{\mathrm{me}}^{3}}{D_{\mathrm{m}}^{3}}$.

\subsubsection{Determination of the coating thickness}

The mass ratio $\left(M_{\mathrm{R}}\right)$ of coating to $\mathrm{rBC}$ core was used to represent the coating thickness in this study. The mass of the rBC-containing particle $\left(M_{\mathrm{p}}\right)$ was directly measured by CPMA and the mass of the $\mathrm{rBC}$ core $\left(M_{\mathrm{rBC}}\right)$ was measured by SP2. Then, the $M_{\mathrm{R}}$ was calculated by Eq. (5):

$M_{\mathrm{R}}=\frac{M_{\mathrm{p}}-M_{\mathrm{rBC}}}{M_{\mathrm{rBC}}}$.

The uncertainty of $M_{\mathrm{R}}$ was determined to be $31.6 \%$ and the uncertainties of the major parameters used in this paper can be found in the Supplement.

\section{Results}

\subsection{Constraining factors of effective density}

The temporal variation in the number concentrations of $\mathrm{rBC}$ containing and non-rBC particles and the mass concentration of non-refractory $\mathrm{PM}_{2.5}\left(\mathrm{NR}-\mathrm{PM}_{2.5}\right)$ measured by a time-offlight aerosol chemical speciation monitor (ToF-ACSM) are shown in Fig. 1. Four pollution events and one lasting clean episode were observed during the study period and were denoted EP 1-5. EP 3 was defined as the clean episode with a $\mathrm{PM}_{2.5}$ mass concentration less than $10 \mu \mathrm{g} \mathrm{cm}^{-3}$. The $\mathrm{PM}_{2.5}$ mass concentration was higher than $50 \mu \mathrm{g} \mathrm{cm}^{-3}$ during the other four pollution episodes. The backward trajectories of the five episodes are illustrated in Fig. S4. Beijing was majorly affected by the local air mass or southern polluted air mass during the pollution episodes. In contrast, the clean northwest air mass dominated in Beijing during the clean episode.

For simplicity, the effective densities of non-rBC and rBCcontaining particles were called $\rho_{\text {non-rBC }}$ and $\rho_{\mathrm{rBC}}$ separately. The effective density of bulk non-rBC and $\mathrm{rBC}$-containing particles calculated by Eq. (2) was called $\rho_{\text {non-rBC,bulk }}$ and 




Figure 1. Time series of (a) the $\mathrm{PM}_{2.5}$ mass concentration; (b) number counts of rBC-containing particles with different effective densities; (c) number fractions of $\mathrm{rBC}$-containing particles with different effective densities; (d) number counts of non-rBC particles with different effective densities; (e) number fractions of non-rBC particles with different effective densities; (f) mass concentrations of aerosol species, including organics, sulfate, nitrate, ammonium, and chloride, in NR-PM 2.5 ; and (g) mass fractions of aerosol species in NR-PM 2.5 during the five episodes denoted at the top of the graph.

$\rho_{\mathrm{rBC} \text {,bulk }}$. The bulk effective density reflects the number distribution of particles with different effective densities. For example, the number fractions of non-rBC particles with lower $\rho_{\text {non-rBC }}\left(0.8-1.2 \mathrm{~g} \mathrm{~cm}^{-3}\right)$ were $\sim 70 \%$ during EP 2 and EP 4 , and this value was significantly lower $(\sim 20 \%)$ during EP 1 and EP 5. Correspondingly, the $\rho_{\text {non-rBC,bulk was calculated }}$ to be 1.18 and $1.20 \mathrm{~g} \mathrm{~cm}^{-3}$ in EP 2 and EP 4, lower than 1.43 and $1.40 \mathrm{~g} \mathrm{~cm}^{-3}$ in EP 1 and EP 5. The variation in $\rho_{\text {non-rBC }}$ was mainly caused by different non-rBC compositions in different cases since the $\rho_{\text {eff }}$ of different compositions varies. The $\rho_{\text {eff }}$ value of $\left(\mathrm{NH}_{4}\right)_{2} \mathrm{SO}_{4}$ and $\mathrm{NH}_{4} \mathrm{NO}_{3}$ particles was $1.75 \mathrm{~g} \mathrm{~cm}^{-3}$ (Qiao et al., 2018), whereas that of organics depended on their compositions and usually was between 0.64 and $1.49 \mathrm{~g} \mathrm{~cm}^{-3}$ (Malloy et al., 2009; Hallquist et al., 2009; Bahreini et al., 2005; Turpin and Lim, 2001).

Turpin and Lim (2001) suggested an overall $\rho_{\text {eff }}$ of $1.2 \mathrm{~g} \mathrm{~cm}^{-3}$ for organic aerosols in Los Angeles, and Hallquist et al. (2009) recommended a $\rho_{\text {eff }}$ of $1.4 \mathrm{~g} \mathrm{~cm}^{-3}$ for secondary organic aerosols in the absence of direct measurement. In general, the $\rho_{\text {eff }}$ values of organics are always lower than those of inorganic compounds. The lower $\rho_{\text {non-rBC }}$ may indicate a higher mass fraction of organic compounds in the nonrBC particles. In fact, although the composition may slightly differ between NR-PM 2.5 and particles with $D_{\mathrm{mob}}=240 \mathrm{~nm}$ as observed in this study, the higher organic fractions in NR$\mathrm{PM}_{2.5}$ in EP 2 and EP $4(66 \%$ and $59 \%)$ may indicate an organic dominant pollution environment and thus a higher organic fraction in particles with $D_{\mathrm{mob}}=240 \mathrm{~nm}$ consistent with the lower $\rho_{\text {non-rBC,bulk }}$ in these two episodes. Furthermore, the relationship between effective density and organic fraction was assessed throughout the observation period, as shown in Fig. S5. The $\rho_{\text {non-rBC,bulk value was apparently low }}$ in the high organic fraction environment during the whole observation period. The $\rho_{\mathrm{rBC}}$,bulk was also lower in the more organic fraction condition similar to that of the non-rBC particles, which was mostly due to composition of coating matter. In this study we presumed that, first, a lower $\rho_{\text {non-rBC,bulk }}$ value means a higher organic fraction in the non-rBC parti- 

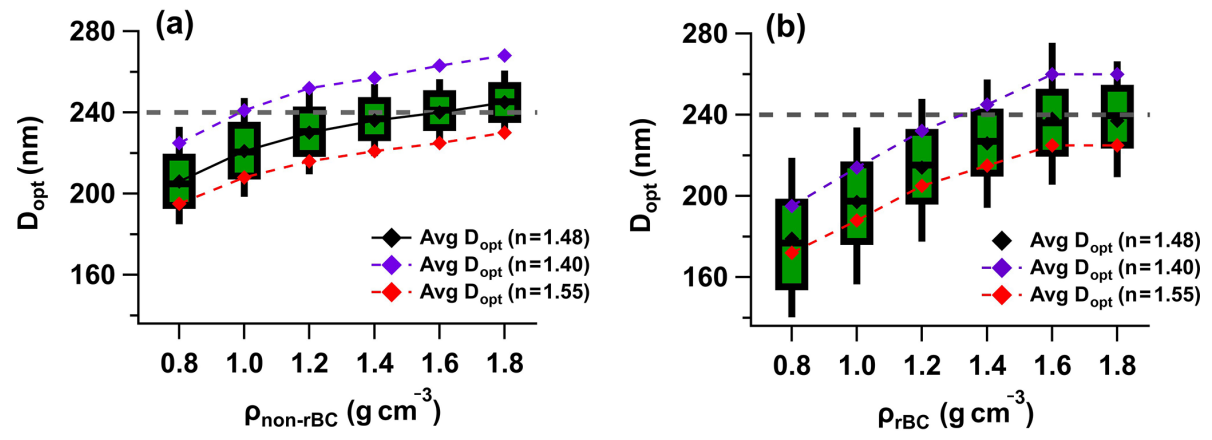

Figure 2. The optical diameters of particles with different effective densities. (a) Non-rBC particles and (b) BC-containing particles. (The black lines in the middle signify the medians; the black markers in the middle denote the means; the upper and lower bounds of the box denote the 75th and 25th percentiles, respectively; and the upper and lower whiskers denote the 90th and 10th percentiles, respectively.) The blue and red dashed lines denote the average optical diameters from different assumptions of the refractive index. The grey dashed line denotes the mobility diameter $\left(D_{\mathrm{mob}}=240 \mathrm{~nm}\right)$ selected by DMA.

cles. Second, composition of non-rBC particles and the coatings of $\mathrm{rBC}$-containing particles were similar.

To better understand the morphological impacts on $\rho_{\text {eff }}$, the optical diameters $\left(D_{\mathrm{opt}}\right)$ of non-rBC and $\mathrm{rBC}$-containing particles were compared to those of $D_{\mathrm{mob}}$, as shown in Fig. 2 . The particle shapes are spherical if $D_{\mathrm{mob}}$ is the same as $D_{\mathrm{opt}}$ since the structure is assumed to be spherical in the $D_{\mathrm{opt}}$ calculation through Mie theory. For non-rBC particles with a $\rho_{\text {non-rBC }}$ larger than $1.4 \mathrm{~g} \mathrm{~cm}^{-3} D_{\text {mob }}$ and $D_{\text {opt }}$ are nearly the same. For non-rBC particles with a $\rho_{\text {non-rBC }}=1.0$ or $1.2 \mathrm{~g} \mathrm{~cm}^{-3}$ the $D_{\text {opt }}$ is slightly lower than the $D_{\text {mob. }}$. The refractive indices for $\left(\mathrm{NH}_{4}\right)_{2} \mathrm{SO}_{4}, \mathrm{NaCl}$, and secondary organic aerosols have been determined to be 1.51, 1.53, and 1.44-1.5, respectively (Nakayama et al., 2010; Schnaiter et al., 2003; Toon et al., 1976). An even lower refractive index (1.42) was found for ambient non-rBC particles (Zhang et al., 2018). The constant refractive index of 1.48 may underestimate the $D_{\text {opt }}$ of non-rBC particles with lower $\rho_{\text {non-rBC }}$ since the refractive indices of organic aerosols may be lower than those of inorganics. Different refractive index assumptions were used to calculate the $D_{\mathrm{opt}}$, as denoted by the red and blue dashed lines in Fig. 2. When the variation in the refractive indices was taken into account, the $D_{\text {opt }}$ was considered to be the same as the $D_{\text {mob }}$ for non-rBC particles with a $\rho_{\text {non-rBC }}=1.0$ or $1.2 \mathrm{~g} \mathrm{~cm}^{-3}$. For non-rBC particles with a $\rho_{\text {non-rBC }}$ of $0.8 \mathrm{~g} \mathrm{~cm}^{-3}$, the lower $D_{\text {opt }}$ may be caused by the lower refractive indices for some specific compounds or the nonspherical morphology. However, the fraction of this non$\mathrm{rBC}$ was negligible, as shown in Fig. 1. Thus, the non-rBC particles mostly adopted a spherical structure.

The mean $D_{\text {opt }}$ was 179,197 , and $214 \mathrm{~nm}$ for rBCcontaining particles with a $\rho_{\mathrm{rBC}}=0.8,1.0$, and $1.2 \mathrm{~g} \mathrm{~cm}^{-3}$, respectively, which were significantly lower than the $D_{\text {mob }}$ values. This decrease could not be explained by variation in the refractive indices, as shown in Fig. $2 b$, indicating that the morphologies of these $\mathrm{rBC}$-containing particles were not spherical. The $D_{\text {opt }}$ was the same as the $D_{\text {mob }}$ when the $\rho_{\mathrm{rBC}}$ was equal to 1.6 or $1.8 \mathrm{~g} \mathrm{~cm}^{-3}$, suggesting that the particles approximate to spherical structure. $\mathrm{rBC}$-containing particles with a $\rho_{\mathrm{rBC}}=1.4 \mathrm{~g} \mathrm{~cm}^{-3}$ were placed at the morphological transition point. The differences between the 75 th and 25 th percentiles of the $D_{\text {opt }}$ were larger for the rBC-containing particles than for the non-rBC particles, as denoted by the box length. This larger difference may be caused by the complex morphology of $\mathrm{rBC}$-containing particles compared to that of non-rBC particles. In general, the non-rBC particles mostly had a spherical structure, and the $\rho_{\text {non-rBC }}$ was majorly influenced by the composition. A lower fraction of organics contributed to the increase in the $\rho_{\text {non-rBC}}$. The $\rho_{\mathrm{rBC}}$ was controlled by the combined effect of the morphology and coating composition. A fractal structure and a more organic coating tend to decrease the $\rho_{\mathrm{rBC}}$.

\subsection{The relationship between the morphology and effective density of rBC-containing particles}

Figure 3 depicts the variations in the $\chi$ and $R_{\text {void }}$ values as a function of $\rho_{\mathrm{rBC}} \cdot \chi$ is a physical index representing the regularity of a particle; the theoretical $\chi$ for a spherical particle is 1 regardless of the void inside, and a larger $\chi$ means a more irregular particle (Decarlo et al., 2004). In practice, the $\chi$ of rBC-containing particles ranges from 1 to 4 (Table 2) mostly due to the combustion material, combustion temperature, aging degree, etc. The largest $\chi$ (1.4) observed in this study was lower than that of freshly emitted rBC-containing particles from a diesel truck $(\chi=2.1)$, methane flame $(\chi=1.87)$, and propane flame $(\chi=4.0)$ and was in the range $(\chi=1-$ 2.8 ) of rBC-containing particles with different aging degrees (Qiu et al., 2014; Peng et al., 2016). Zhang et al. (2016) suggested that the $\rho_{\mathrm{rBC}}$ of thinly coated $\mathrm{rBC}$-containing particles was $0.3 \mathrm{~g} \mathrm{~cm}^{-3}$. Direct measurements of vehicle exhaust always obtain a $\rho_{\mathrm{rBC}}$ of $0.3-0.5 \mathrm{~g} \mathrm{~cm}^{-3}$ (Momenimovahed and Olfert, 2015). Because the lower detection limit of $\rho_{\mathrm{rBC}}$ was set to $0.8 \mathrm{~g} \mathrm{~cm}^{-3}$, fresh $\mathrm{rBC}$-containing particles 
(a)

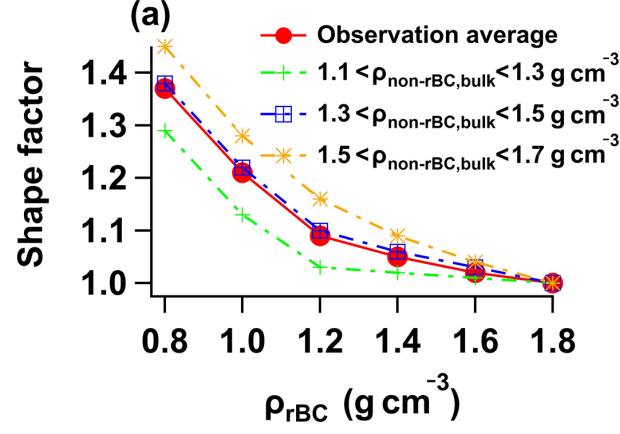

(b)

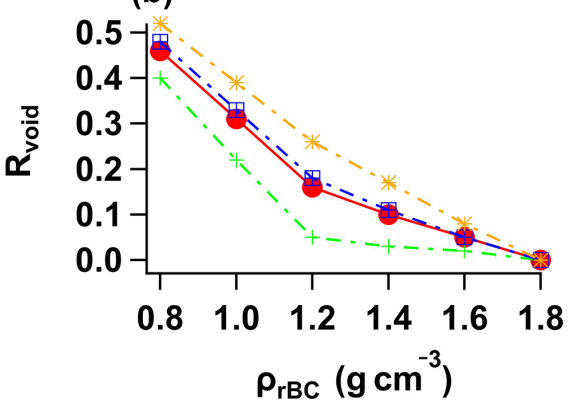

Figure 3. The shape factor and void fraction of BC-containing particles under different effective densities.

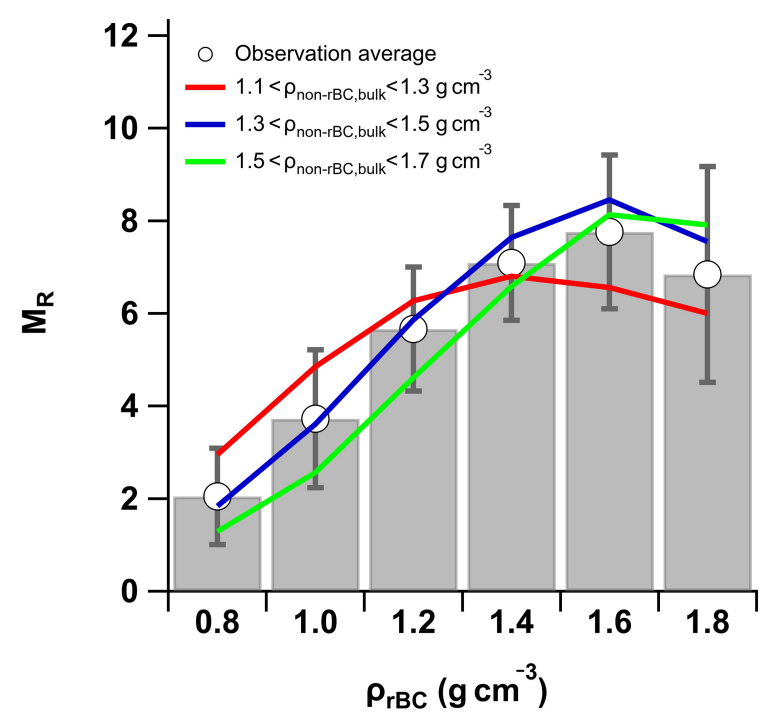

Figure 4. Variation in mass ratio $\left(M_{\mathrm{R}}\right)$ of coatings to $\mathrm{rBC}$ as a function of $\rho_{\mathrm{rBC}}$.

might not have been observed in this study. Indeed, the rBCcontaining particles observed in this study were actually aged rBC-containing particles with moderate irregularity.

The $\chi$ values showed a decreasing trend with the increasing $\rho_{\mathrm{rBC}}$, indicating a more regular shape for $\mathrm{rBC}$-containing particles with a larger $\rho_{\mathrm{rBC}}$, which was consistent with previous studies (Qiu et al., 2014; Peng et al., 2016). When the $\rho_{\mathrm{rBC}}$ is less than $1.4 \mathrm{~g} \mathrm{~cm}^{-3}$, the $\chi$ decreases significantly with the increase in $\rho_{\mathrm{rBC}}$. However, $\chi$ varies slowly between 1 and 1.1 when the $\rho_{\mathrm{rBC}}$ is larger than $1.4 \mathrm{~g} \mathrm{~cm}^{-3}$. A similar variation trend was also found for $R_{\text {void }} \cdot R_{\text {void }}$ decreases significantly from 0.5 to 0.1 and varies slowly between 0.1 and 0 when the $\rho_{\mathrm{rBC}}$ is larger than $1.4 \mathrm{~g} \mathrm{~cm}^{-3}$. These results are similar to those from the comparison between $D_{\text {opt }}$ and $D_{\text {mob}}$; the morphology of $\mathrm{rBC}$-containing particles changed from an irregular and loose structure to a compact spherical structure with the increasing $\rho_{\mathrm{rBC}}$. Thus, a $\rho_{\mathrm{rBC}}$ of $1.4 \mathrm{~g} \mathrm{~cm}^{-3}$ may be the morphological transition point in this study. Using a smog chamber, Peng et al. (2016) also observed a change in the $\rho_{\mathrm{rBC}}$ from $\sim 0.5$ to $1.4 \mathrm{~g} \mathrm{~cm}^{-3}$ during the aging process and found that $\mathrm{rBC}$-containing particles with a $\rho_{\mathrm{rBC}}=1.4 \mathrm{~g} \mathrm{~cm}^{-3}$ had a $\chi \sim 1$.

We found that $\mathrm{rBC}$-containing particles had a larger $\chi$ value and $R_{\text {void }}$ at the condition when $\rho_{\text {non-rBC,bulk }}$ is smaller, especially for irregular particles (Fig. 3a). This may imply that different coating composition played a different role in the morphology reconstruction of $\mathrm{rBC}$-containing particles because $\rho_{\text {non-rBC,bulk }}$ reflected the composition of non-rBC, which may relate to the coating composition of $\mathrm{rBC}$ to some degree (Fig. S6). The rBC-containing particles could reach a compact spherical structure when the $\rho_{\mathrm{rBC}}$ was $1.2 \mathrm{~g} \mathrm{~cm}^{-3}$ with an $\chi$ of 1.05 and a $R_{\text {void }}$ of 0.08 when $1.1 \mathrm{~g} \mathrm{~cm}^{-3}<$ $\rho_{\text {non-rBC,bulk }}<1.3 \mathrm{~g} \mathrm{~cm}^{-3}$, whereas the morphological transition of $\rho_{\mathrm{rBC}}$ was higher for $\mathrm{rBC}$-containing particles at a higher $\rho_{\text {non-rBC,bulk }}$ condition.

\subsection{Mass ratio of coatings to the $\mathrm{rBC}$ core of rBC-containing particles with different $\rho_{\text {eff }}$ values}

The mass ratio $\left(M_{\mathrm{R}}\right)$ of the coating to the $\mathrm{rBC}$ core is used to represent the coating thickness in this study. The coating thickness is an index of the aging degree of rBC-containing particles since condensation and coagulation will lead to an increase in the coating thickness during the aging process. As shown in Fig. 4, rBC-containing particles with larger $\rho_{\mathrm{rBC}}$ values had more coating. This phenomenon explains the morphological change that occurs with an increasing $\rho_{\mathrm{rBC}}$. The surface tension imposed by the coating was found to shrink the rBC core (Zhang et al., 2016). After coating, rBCcontaining particles with larger hygroscopicity more easily obtain surface water, which enlarges the surface tension and shrinks the rBC-containing particles to a more compact structure (Zhang et al., 2008). Moreover, the coatings are able to fill the void of $\mathrm{rBC}$-containing particles, resulting in a more compact structure (Pagels et al., 2009). Thus, increasing the coating makes $\mathrm{rBC}$-containing particles more compact, and the compact structure leads to a larger effective density, as observed.

Recently, studies using different methods have proven the occurrence of morphological change of rBC-containing par- 
Table 2. Brief summary of the effective density and dynamic shape factor of rBC-containing particles.

\begin{tabular}{|c|c|c|c|c|}
\hline Particle type & Shape factor* & Effective density* $\left(\mathrm{g} \mathrm{cm}^{-3}\right)$ & Description & Reference \\
\hline Ambient & - & $1.42(0.39)$ & $\begin{array}{l}\text { The } \rho_{\text {eff }} \text { distribution exhibits a bimodal } \\
\text { pattern. The left peak is contributed by } \\
\text { fresh soot with a } \rho_{\text {eff }} \text { of } 0.39 \mathrm{~g} \mathrm{~cm}^{-3} \text {. }\end{array}$ & Rissler et al. (2014) \\
\hline Ambient & - & $1.50(0.8)$ & Similar bimodal $\rho_{\text {eff }}$ distribution. & Qiao et al. (2018) \\
\hline $\begin{array}{l}\text { Non-rBC } \\
\text { (dioctyl sebacate) }\end{array}$ & 1.03 & 0.931 & $\begin{array}{l}\text { The shape factor is nearly } 1 \text { for } \\
\text { non-rBC particles. }\end{array}$ & $\begin{array}{l}\text { Tavakoli and } \\
\text { Olfert (2014) }\end{array}$ \\
\hline \multirow{6}{*}{$\begin{array}{l}\text { rBC-containing } \\
\text { particles }\end{array}$} & 2.10 & 1.00 & $\begin{array}{l}\text { rBC-containing particles from a diesel } \\
\text { truck. }\end{array}$ & Han et al. (2019) \\
\hline & 4 & 0.18 & $\begin{array}{l}\text { rBC-containing particles generated } \\
\text { from a propane flame. }\end{array}$ & \multirow[t]{2}{*}{ Xue et al. (2009) } \\
\hline & 1.80 & 0.70 & $\begin{array}{l}\text { Propane flame rBC-containing particles } \\
\text { coated with glutaric acid. }\end{array}$ & \\
\hline & 1.87 & 0.50 & $\begin{array}{l}\text { rBC-containing particles generated } \\
\text { from a methane flame. }\end{array}$ & $\begin{array}{l}\text { Tavakoli and Olfert } \\
\text { (2014) }\end{array}$ \\
\hline & $1.03-2.79$ & $1.36-0.25$ & $\begin{array}{l}\text { Diesel exhaust rBC-containing parti- } \\
\text { cles with different combustion tem- } \\
\text { peratures; the rBC-containing particles } \\
\text { were more compact from the lower- } \\
\text { temperature combustion condition. }\end{array}$ & Qiu et al. (2014) \\
\hline & $1-2.8$ & $1.4-0.25$ & $\begin{array}{l}\text { Laboratory-generated } \mathrm{rBC} \text {-containing } \\
\text { particles with different aging times; } \\
\text { the } \mathrm{rBC} \text {-containing particles were more } \\
\text { compact when undergoing a long aging } \\
\text { process. }\end{array}$ & Peng et al. (2016) \\
\hline
\end{tabular}

* The effective density and shape factor counted in this table are for rBC-containing particles with a $D_{\text {mob }}=240 \pm 20 \mathrm{~nm}$.

ticles with an increase in the coating thickness. Peng et al. (2016) observed that rBC-containing particles changed to a compact spherical structure when the ratio of the coating thickness to the $\mathrm{rBC}$ core diameter reached $0.8-1$, corresponding to a $M_{\mathrm{R}}$ of 4.5-6.5. By comparing the measured and modeled scattering cross sections of rBC-containing particles, Liu et al. (2017) found that the measured scattering cross section agreed well with the core-shell model prediction when the $M_{\mathrm{R}}$ was larger than 3, suggesting adoption of a spherical morphology by rBC-containing particles with a large $M_{\mathrm{R}}$. The morphology of $\mathrm{rBC}$-containing particles seems to change to be spherical at a certain $M_{\mathrm{R}}$ point. In this study, the $M_{\mathrm{R}}$ was nearly invariant and fluctuated between 6 and 8 when the $\rho_{\text {eff }}$ was larger than $1.4 \mathrm{~g} \mathrm{~cm}^{-3}$, suggesting that the $\mathrm{rBC}$-containing particles were mostly spherical in structure when the $M_{\mathrm{R}}$ was larger than 6-8.

In the real atmosphere, the variant temperature and relative humidity may also contribute to the morphological variation in rBC-containing particles, which makes the morphological transition $M_{\mathrm{R}}$ point more complicated and thus different from that reported in previous studies. However, an agreement has been reached concerning the mechanism by which the morphology changes with the increasing coating thickness. A $M_{\mathrm{R}}$ of 7 was determined to be the morphological transition point in Beijing in winter. The morphological transition $M_{\mathrm{R}}$ or volume ratio may be very useful for parameterization in atmospheric models. Thus, more observations are needed to explore the variation in and constraining factors of the morphological transition $M_{\mathrm{R}}$.

Previous studies have always used a shell / core ratio ( $\mathrm{S} / \mathrm{C})$ to represent the coating thickness. The $M_{\mathrm{R}}$ of $\mathrm{rBC}-$ containing particles with a $\rho_{\mathrm{rBC}}=0.8 \mathrm{~g} \mathrm{~cm}^{-3}$ averaged 2.0 , corresponding to an $\mathrm{S} / \mathrm{C}$ of 1.5 , and the $M_{\mathrm{R}}$ of $\mathrm{rBC}-$ containing particles with a $\rho_{\mathrm{rBC}}=1.4 \mathrm{~g} \mathrm{~cm}^{-3}$ averaged 7.0, corresponding to an $\mathrm{S} / \mathrm{C}$ of 2.15 . Typically, the $\mathrm{S} / \mathrm{C}$ ratio of freshly emitted BC observed at urban sites was lower than 1.2 (Liu et al., 2014; Laborde et al., 2013). In this study, rBCcontaining particles with a $\rho_{\mathrm{rBC}}$ of $0.8 \mathrm{~g} \mathrm{~cm}^{-3}$ were characterized as having an irregular and loose structure with $\chi=1.4$ and $R_{\text {void }}=0.5$. Since the $\rho_{\mathrm{rBC}}$ increased with the increase in the $M_{\mathrm{R}}$ or $\mathrm{S} / \mathrm{C}$, the observed average $\mathrm{S} / \mathrm{C}=1.2$ at the urban site suggested that most $\mathrm{rBC}$-containing particles at the urban site might have a $\rho_{\mathrm{rBC}}$ lower than $0.8 \mathrm{~g} \mathrm{~cm}^{-3}$ and thus a more irregular structure. 

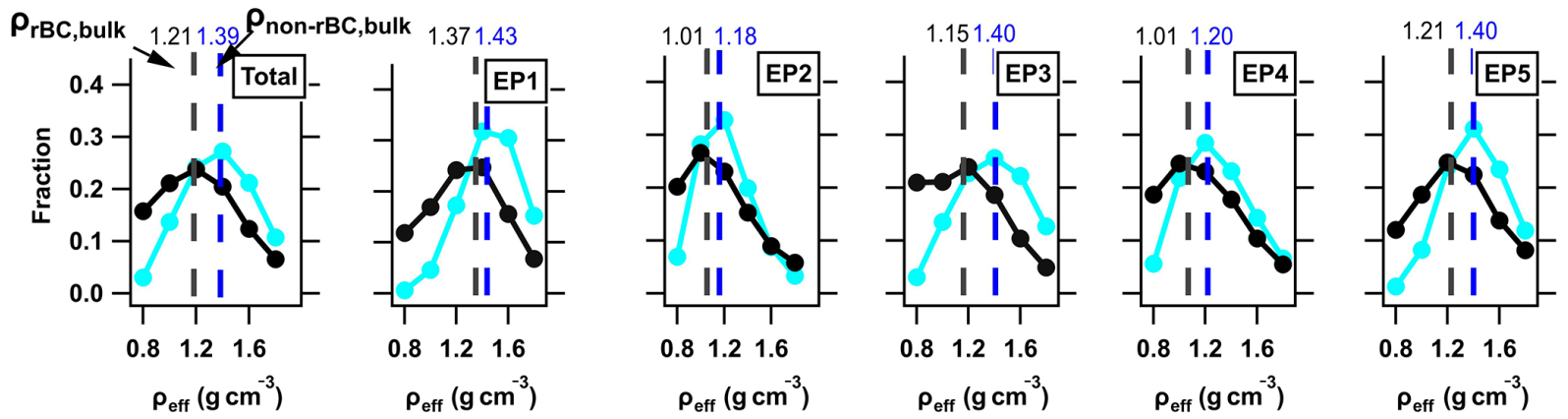

Figure 5. Number distributions of rBC-containing particles (black lines) and non-rBC particles (blue lines) with different effective densities during different episodes. The black dashed line denotes the effective density of bulk rBC-containing particles, and the blue dashed line denotes the effective density of bulk non-rBC particles.

\subsection{The morphology of bulk rBC-containing particles}

The number distributions of $\rho_{\mathrm{rBC}}$ and $\rho_{\text {non-rBC }}$ were counted to evaluate the morphological characteristics of the bulk rBCcontaining particles in the ambient environment, as shown in Fig. 5. Generally, the $\rho_{\mathrm{rBC}}$ and $\rho_{\text {non-rBC }}$ number distributions exhibited a unimodal distribution except for the $\rho_{\mathrm{rBC}}$ distribution in EP 3 (the clean period). Observations of $\mathrm{rBC}$ containing particles indicated that the coating thickness distribution always exhibited a clear bimodal pattern (Liu et al., 2014; Wu et al., 2017). rBC-containing particles were observed with a thin coating, which was mostly attributed to local traffic emissions, and with a thick coating, which might be the result of biomass emissions or the aging process. The aged $\mathrm{rBC}$-containing particles with a $\rho_{\mathrm{rBC}}>0.8 \mathrm{~g} \mathrm{~cm}^{-3} \mathrm{ob}-$ served in this study may exactly correspond to the rBCcontaining particles with a thick coating and thus exhibit a unimodal pattern. We speculate that the $\rho_{\mathrm{rBC}}$ number distribution will exhibit a bimodal pattern if the detection limit is sufficiently low and the left peak in the expected bimodal pattern corresponds to the $\mathrm{rBC}$-containing particles with thin coatings. The $\rho_{\mathrm{rBC}}$ distribution in EP 3 may be influenced by the thinly coated $\mathrm{rBC}$-containing particles, which might be present in relatively higher numbers during the clean period.

The $\rho_{\mathrm{rBC}, \text { bulk }}$ and $\rho_{\text {non-rBC,bulk }}$ were separately estimated to be 1.21 and $1.39 \mathrm{~g} \mathrm{~cm}^{-3}$, respectively, throughout the observation period. Notably, due to the detection limit, the $\rho_{\mathrm{rBC}}$,bulk in this study was determined for aged $\mathrm{rBC}-$ containing particles, and the true $\rho_{\mathrm{rBC}}$,bulk was expected to be lower if fresh $\mathrm{rBC}$-containing particles were taken into consideration. However, even for these aged $\mathrm{rBC}$-containing particles, the morphology was mostly in a fractal structure because the $\rho_{\mathrm{rBC} \text {,bulk }}\left(1.21 \mathrm{~g} \mathrm{~cm}^{-3}\right)$ was smaller than the morphological transition $\rho_{\mathrm{rBC}}\left(1.40 \mathrm{~g} \mathrm{~cm}^{-3}\right)$. Wang et al. (2017) proved that only $12 \%$ of $\mathrm{rBC}$-containing particles were in an embedded structure and that $88 \%$ of rBC-containing particles were in a bare or partly coated structure at urban sites through direct TEM observation. Our results provided evi-

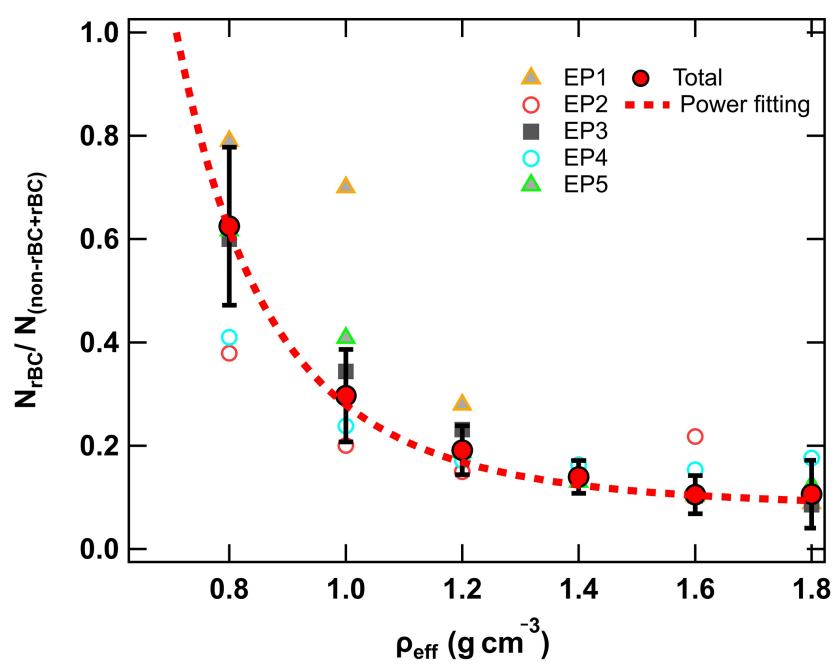

Figure 6. Number fractions of rBC-containing particles in the total particles (rBC-containing and non-rBC particles) under different effective densities.

dence for the irregularity of rBC-containing particles based on assessment of more particle numbers.

The $\rho_{\text {eff }}$ was separately counted in the five episodes, as shown in Fig. 5, to investigate variation in $\rho_{\text {eff }}$ under different pollution situations. The $\rho_{\mathrm{rBC}}$,bulk was $1.37,1.01,1.15$, 1.01 , and $1.21 \mathrm{~g} \mathrm{~cm}^{-3}$ during EP $1-5$, and the corresponding $\rho_{\text {non-rBC,bulk was }} 1.43,1.18,1.40,1.20$, and $1.40 \mathrm{~g} \mathrm{~cm}^{-3}$, respectively. According to Fig. 3a, the morphological transition $\rho_{\mathrm{rBC}}$ points were $1.2 \mathrm{~g} \mathrm{~cm}^{-3}$ in EP 2 and EP 4 and $1.4 \mathrm{~g} \mathrm{~cm}^{-3}$ in EP 1, EP 3, and EP 5 due to the different $\rho_{\text {non-rBC,bulk }}$ values. The $\rho_{\mathrm{rBC}}$,bulk in the five episodes was lower than that of the morphological transition $\rho_{\mathrm{rBC}}$ regardless of the pollution conditions, indicating that a substantial number of rBC-containing particles were in a fractal structure even under pollution conditions. However, the $\rho_{\mathrm{rBC}}$,bulk in EP3 was smaller than that in EP1 and EP5, which might suggest a more compact structure of $\mathrm{rBC}$-containing particles in pollu- 


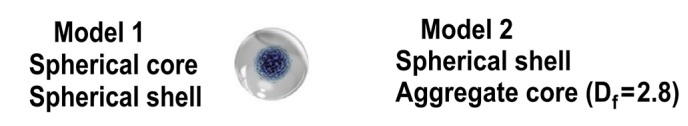

(a)

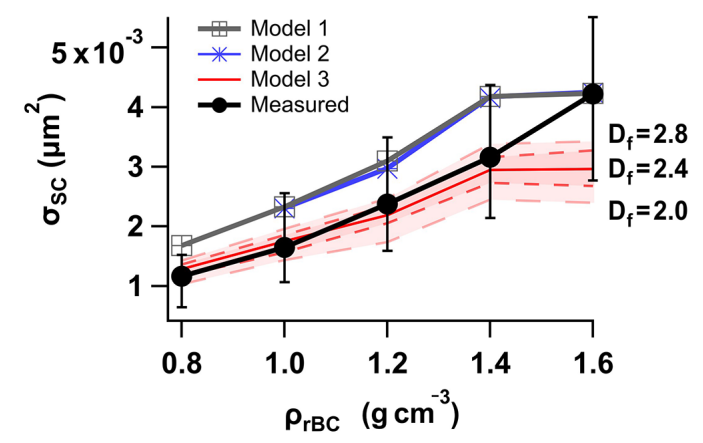

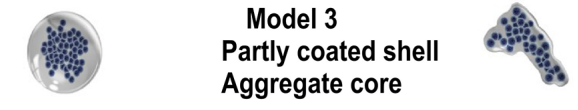

(b)

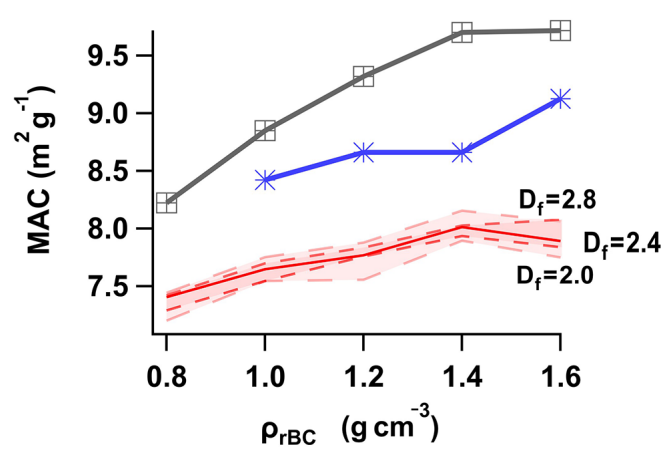

Figure 7. (a) The scattering cross section of BC-containing particles at the $1064 \mathrm{~nm}$ wavelength predicted by different models and measured by the SP2 under different effective densities. (b) The mass absorption cross section at the $532 \mathrm{~nm}$ wavelength predicted by different models under different effective densities. Model 3 was used with various assumptions of the core fractal dimension $\left(D_{\mathrm{f}}=2.0,2.2,2.4,2.6\right.$, and 2.8) as denoted in the graph.

tion conditions since the morphological transition $\rho_{\mathrm{rBC}}$ was similar during these three episodes.

The number fraction of $\mathrm{rBC}$-containing particles in the total measured particles (rBC-containing and non-rBC particles) increased with the decrease in the $\rho_{\text {eff }}$, as shown in Fig. 6. rBC-containing particles only accounted for $10 \%-$ $20 \%$ of particles with a $\rho_{\text {eff }}=1.6 \mathrm{~g} \mathrm{~cm}^{-3}$, whereas this fraction significantly increased to $\sim 60 \%$ for particles with a $\rho_{\text {eff }}=0.8 \mathrm{~g} \mathrm{~cm}^{-3}$. The data from the five episodes all followed the same tendency, and the maximum number fraction of rBC-containing particles was reached when the $\rho_{\text {eff }}$ was equal to $0.8 \mathrm{~g} \mathrm{~cm}^{-3}$. A power function was used to fit the data and showed that the number fraction of $\mathrm{rBC}$ would be $100 \%$ if the $\rho_{\text {eff }}$ were less than $0.73 \mathrm{~g} \mathrm{~cm}^{-3}$. Rissler et al. (2014) observed a bimodal $\rho_{\text {eff }}$ distribution of ambient aerosols. The $\rho_{\text {eff }}$ of aerosols in the two peaks ranged separately from 0.30 to 0.80 and 1.28 to $1.46 \mathrm{~g} \mathrm{~cm}^{-3}$. The mass of aerosols with a $\rho_{\text {eff }}$ of $0.30-0.80 \mathrm{~g} \mathrm{~cm}^{-3}$ only lost $10 \%$ after being heated to $300^{\circ} \mathrm{C}$, indicating that most of these particles were fresh $\mathrm{rBC}$-containing particles, which was consistent with our inference. Thus, if the measurement site was located in an area with enough fresh BC emission, the bimodal $\rho_{\text {eff }}$ distribution of ambient aerosols was often observed (Qiao et al., 2018; Liu et al., 2015; Rissler et al., 2014) since the $\rho_{\text {eff }}$ of fresh rBC-containing particles was sufficiently small with no disturbance by non-rBC particles. However, as shown in Fig. 6, the $\rho_{\text {eff }}$ distributions of non$\mathrm{rBC}$ and aged $\mathrm{rBC}$-containing particles overlapped and could not be distinguished through a simple DMA-APM/CPMACPC system. Our study suggested that the second peak often observed in previous $\rho_{\text {eff }}$ measurements was actually a mixture of non-rBC and aged rBC-containing particles. Rissler et al. (2014) used "dense" particles to describe particles with a $\rho_{\text {eff }}$ of $1.28-1.46 \mathrm{~g} \mathrm{~cm}^{-3}$. This expression might be not very accurate since nearly $10 \%-40 \%$ of the particles were aged rBC-containing particles with a fractal structure $(\chi=1-1.2)$.

\subsection{Optical properties of $\mathrm{rBC}$-containing particles with different $\rho_{\text {eff }}$ values}

Since the morphology of rBC-containing particles was mostly in a fractal structure as discussed above, the simple core-shell structure treatment in the atmospheric model might cause bias in the optical property estimate of rBCcontaining particles. An aggregate model was established, and the optical properties were calculated by solving Maxwell's equation based on the superposition T-matrix method (Wu et al., 2018). As shown in Fig. 7a, large discrepancies in the scattering cross sections $\left(\sigma_{\mathrm{SC}}\right)$ between the core-shell model and measurement were found in the small $\rho_{\mathrm{rBC}}$ range, indicating the strong impact of morphology on optical properties. An aggregate model can better capture the $\sigma_{\mathrm{SC}}$ characteristics than a perfect shell-core model when the $\rho_{\mathrm{rBC}}$ is smaller than $1.4 \mathrm{~g} \mathrm{~cm}^{-3}$. When the $\rho_{\mathrm{rBC}}$ is $0.8 \mathrm{~g} \mathrm{~cm}^{-3}$, the $\sigma_{\mathrm{SC}}$ predicted by the aggregate model with a $\mathrm{rBC}$ core fractal dimension $\left(D_{\mathrm{f}}\right)$ of 2.0-2.2 agrees well with the measurement. With an increase in the $\rho_{\mathrm{rBC}}$, the measured $\sigma_{\mathrm{SC}}$ is consistent with the predicted value from the aggregate model obtained using the larger $\mathrm{rBC}$ core fractal dimension. This result may imply that the $\mathrm{rBC}$ core becomes more compact and regular with an increase in the $\rho_{\mathrm{rBC}}$ or coating thickness consistent with the laboratory results (Pagels et al., 2009; Xue et al., 2009).

Figure $7 \mathrm{~b}$ exhibits the estimated mass absorption cross sections (MACs) from different models. The overestimation of the MAC using the core-shell structure averaged $16.7 \%$ compared to that of the aggregate model when the $\rho_{\mathrm{rBC}}$ 
was less than $1.4 \mathrm{~g} \mathrm{~cm}^{-3}$. Additionally, the measured $\sigma_{\mathrm{SC}}$ with a $\rho_{\mathrm{rBC}}=1.6 \mathrm{~g} \mathrm{~cm}^{-3}$ was similar to the predicted values of models 1 and 2, indicating a near-spherical structure of the $\mathrm{rBC}$-containing particles. However, the MAC predicted by models 1 and 2 varied. Although laboratory studies proved that the $\mathrm{rBC}$ core shrank after coating, an irregular $\mathrm{rBC}$ core was often observed even in thickly coated cases in the ambient measurement (Adachi et al., 2010; Zhang et al., 2016), suggesting that model 2 might be closer to the realistic thickly coated situation. Since model 1 overestimated the MAC by $7.4 \%$ with a $\rho_{\mathrm{rBC}}=1.6 \mathrm{~g} \mathrm{~cm}^{-3}$ compared to that of model 2, the morphology of the $\mathrm{rBC}$ core should also be considered, even in cases with a large $\rho_{\mathrm{rBC}}$ or thickly coated condition. In general, the commonly observed light absorption enhancement in pollution conditions cannot simply be attributed to the "lensing effect". The morphological change of $\mathrm{rBC}$-containing particles and the $\mathrm{BC}$ core may also play an important role in light absorption enhancement.

\section{Conclusion}

A novel tandem DMA-CPMA-SP2 system was used to investigate the effective density of $\mathrm{rBC}$-containing particles $\left(\rho_{\mathrm{rBC}}\right)$ and their relationship with the $\mathrm{rBC}$ mixing state in Beijing. Aerosols with the same mobility diameter $(240 \mathrm{~nm})$ and different $\rho_{\text {eff values }}(0.8,1.0,1.2,1.4,1.6$, and $1.8 \mathrm{~g} \mathrm{~cm}^{-3}$ ) were preselected by the DMA-CPMA system and injected into the SP2 to obtain the corresponding mixing state. The results showed that the $\rho_{\mathrm{rBC}}$ could reflect the morphology of rBC-containing particles. The dynamic shape factor of $\mathrm{rBC}$-containing particles decreased from 1.4 to 1 with the increase in the $\rho_{\mathrm{rBC}}$, indicating that the morphology of the $\mathrm{rBC}$-containing particles changed from an irregular loose structure to a compact spherical structure. $\mathrm{rBC}$-containing particles with $\rho_{\mathrm{rBC}}$ values of $0.8,1.0$, and $1.2 \mathrm{~g} \mathrm{~cm}^{-3}$ mostly adopted a nonspherical structure, whereas those with $\rho_{\mathrm{rBC}}$ values of 1.6 and $1.8 \mathrm{~g} \mathrm{~cm}^{-3}$ had a spherical structure. The $\rho_{\mathrm{rBC}}=1.4 \mathrm{~g} \mathrm{~cm}^{-3}$ was determined to be the morphological transition point in this study. The mass ratio $\left(M_{\mathrm{R}}\right)$ of the coatings to the $\mathrm{rBC}$ core was calculated for $\mathrm{rBC}$-containing particles with different $\rho_{\mathrm{rBC}}$ values. The $M_{\mathrm{R}}$ gradually increased from 2 to $6-8$ with the increase in the $\rho_{\mathrm{rBC}}$ when its measure was less than $1.4 \mathrm{~g} \mathrm{~cm}^{-3}$ and stayed invariant when the $\rho_{\mathrm{rBC}}$ was larger than $1.4 \mathrm{~g} \mathrm{~cm}^{-3}$, suggesting that the increased coating thickness during the aging process was the cause of morphological changes and that the rBC-containing particles tended to be spherical when the $M_{\mathrm{R}}$ was larger than 6-8 in the winter in Beijing.

The morphological characteristics of the bulk ambient rBC-containing particles were investigated by calculating the bulk effective density of rBC-containing particles $\left(\rho_{\mathrm{rBC}}\right.$,bulk $)$ considering the number distribution of $\rho_{\mathrm{rBC}}$. The $\rho_{\mathrm{rBC} \text {,bulk }}$ averaged $1.21 \mathrm{~g} \mathrm{~cm}^{-3}$ during the whole observation period and was lower than the morphological transition $\rho_{\mathrm{rBC}}$ re- gardless of the pollution conditions. The $\rho_{\mathrm{rBC}}$,bulk was overestimated due to the lower detection limit in this study (set to $0.8 \mathrm{~g} \mathrm{~cm}^{-3}$ ), which was larger than the $\rho_{\mathrm{rBC}}$ of freshly emitted rBC-containing particles. However, the $\rho_{\mathrm{rBC}}$,bulk was still lower than the morphological transition $\rho_{\mathrm{rBC}}$, suggesting that the $\mathrm{rBC}$-containing particles were mostly not in a core-shell structure in the ambient condition. An aggregate model considering the morphological information of $\mathrm{rBC}$ containing particles was approved to better represent and to evaluate the optical properties of $\mathrm{rBC}$-containing particles. Generally, the core-shell model overestimated light absorption compared to that of the aggregate model by $16.7 \%$ for $\mathrm{rBC}$-containing particles with a $\rho_{\mathrm{rBC}}=0.8-1.4 \mathrm{~g} \mathrm{~cm}^{-3}$. This study revealed that a substantial number of $\mathrm{rBC}$-containing particles were in an irregular structure in the ambient atmosphere and highlighted the importance of morphology for optical property estimates. A proper parameterization considering rBC-containing particle morphological changes with $M_{\mathrm{R}}$ and a morphology-dependent optical model may help reduce the uncertainty in atmospheric modeling.

Data availability. To request the data given in this study, please contact Xiaole Pan at the Institute of Atmospheric Physics, Chinese Academy of Sciences, via email (panxiaole@mail.iap.ac.cn).

Supplement. The supplement related to this article is available online at: https://doi.org/10.5194/acp-19-14791-2019-supplement.

Author contributions. HL and XP designed the research. YW and HL performed the optical simulation using the T-matrix method. HL, XP, DW, XL, YT, YS, PF, and ZW performed experiments. HL, XP, and YT performed the data analysis. HL and XP wrote the paper.

Competing interests. The authors declare that they have no conflict of interest.

Financial support. This research has been supported by the National Natural Science Foundation of China (grant no. 41605104).

Review statement. This paper was edited by Radovan Krejci and reviewed by two anonymous referees.

\section{References}

Adachi, K. and Buseck, P. R.: Changes of ns-soot mixing states and shapes in an urban area during CalNex, J. Geophys. Res.-Atmos., 118, 3723-3730, https://doi.org/10.1002/jgrd.50321, 2013. 
Adachi, K., Chung, S. H., and Buseck, P. R.: Shapes of soot aerosol particles and implications for their effects on climate, J. Geophys. Res.-Atmos., 115, D15206, https://doi.org/10.1029/2009jd012868, 2010.

Alfoldy, B., Giechaskiel, B., Hofmann, W., and Drossinos, Y.: Size-distribution dependent lung deposition of diesel exhaust particles, J. Aerosol Sci., 40, 652-663, https://doi.org/10.1016/j.jaerosci.2009.04.009, 2009.

Apte, J. S., Marshall, J. D., Cohen, A. J., and Brauer, M.: Addressing Global Mortality from Ambient $\mathrm{PM}_{2.5}$, Environ. Sci. Technol., 49, 8057-8066, https://doi.org/10.1021/acs.est.5b01236, 2015.

Bahreini, R., Keywood, M. D., Ng, N. L., Varutbangkul, V., Gao, S., Flagan, R. C., Seinfeld, J. H., Worsnop, D. R., and Jimenez, J. L.: Measurements of secondary organic aerosol from oxidation of cycloalkenes, terpenes, and m-xylene using an Aerodyne aerosol mass spectrometer, Environ. Sci. Technol., 39, 56745688, https://doi.org/10.1021/es048061a, 2005.

Bond, T. C., Doherty, S. J., Fahey, D., Forster, P., Berntsen, T., DeAngelo, B., Flanner, M., Ghan, S., Kärcher, B., and Koch, D.: Bounding the role of black carbon in the climate system: A scientific assessment, J. Geophys. Res.-Atmos., 118, 5380-5552, 2013.

Cappa, C. D., Onasch, T. B., Massoli, P., Worsnop, D. R., Bates, T. S., Cross, E. S., Davidovits, P., Hakala, J., Hayden, K. L., Jobson, B. T., Kolesar, K. R., Lack, D. A., Lerner, B. M., Li, S. M., Mellon, D., Nuaaman, I., Olfert, J. S., Petaja, T., Quinn, P. K., Song, C., Subramanian, R., Williams, E. J., and Zaveri, R. A.: Radiative Absorption Enhancements Due to the Mixing State of Atmospheric Black Carbon, Science, 337, 1078-1081, https://doi.org/10.1126/science.1223447, 2012.

China, S., Mazzoleni, C., Gorkowski, K., Aiken, A. C., and Dubey, M. K.: Morphology and mixing state of individual freshly emitted wildfire carbonaceous particles, Nat. Commun., 4, 2122, https://doi.org/10.1038/ncomms3122, 2013.

Decarlo, P., Slowik, J., Worsnop, D., Davidovits, P., and Jimenez, J.: Particle Morphology and Density Characterization by Combined Mobility and Aerodynamic Diameter Measurements, Part 1: Theory, Aerosol Sci. Technol., 38, 1185-1205, 2004.

Dominguez-Rodriguez, A., Rodriguez, S., Abreu-Gonzalez, P., Avanzas, P., and Juarez-Prera, R. A.: Black carbon exposure, oxidative stress markers and major adverse cardiovascular events in patients with acute coronary syndromes, Int. J. Cardiol., 188, 47-49, https://doi.org/10.1016/j.ijcard.2015.04.023, 2015.

Flanner, M. G., Zender, C. S., Randerson, J. T., and Rasch, P. J.: Present-day climate forcing and response from black carbon in snow, J. Geophys. Res.-Atmos., 112, D11202, https://doi.org/10.1029/2006JD008003, 2007.

Gao, R. S., Schwarz, J. P., Kelly, K. K., Fahey, D. W., Watts, L. A., Thompson, T. L., Spackman, J. R., Slowik, J. G., Cross, E. S., Han, J. H., Davidovits, P., Onasch, T. B., and Worsnop, D. R.: A novel method for estimating lightscattering properties of soot aerosols using a modified singleparticle soot photometer, Aerosol Sci. Technol., 41, 125-135, https://doi.org/10.1080/02786820601118398, 2007.

Hallquist, M., Wenger, J. C., Baltensperger, U., Rudich, Y., Simpson, D., Claeys, M., Dommen, J., Donahue, N. M., George, C., Goldstein, A. H., Hamilton, J. F., Herrmann, H., Hoffmann, T., Iinuma, Y., Jang, M., Jenkin, M. E., Jimenez, J. L.,
Kiendler-Scharr, A., Maenhaut, W., McFiggans, G., Mentel, Th. F., Monod, A., Prévôt, A. S. H., Seinfeld, J. H., Surratt, J. D., Szmigielski, R., and Wildt, J.: The formation, properties and impact of secondary organic aerosol: current and emerging issues, Atmos. Chem. Phys., 9, 5155-5236, https://doi.org/10.5194/acp9-5155-2009, 2009.

Han, C., Li, S. M., Liu, P., and Lee, P.: Size Dependence of the Physical Characteristics of Particles Containing Refractory Black Carbon in Diesel Vehicle Exhaust, Environ. Sci. Technol., 53, 137-145, https://doi.org/10.1021/acs.est.8b04603, 2019.

Laborde, M., Crippa, M., Tritscher, T., Jurányi, Z., Decarlo, P. F., Temime-Roussel, B., Marchand, N., Eckhardt, S., Stohl, A., Baltensperger, U., Prévôt, A. S. H., Weingartner, E., and Gysel, M.: Black carbon physical properties and mixing state in the European megacity Paris, Atmos. Chem. Phys., 13, 5831-5856, https://doi.org/10.5194/acp-13-5831-2013, 2013.

Lack, D. A., Langridge, J. M., Bahreini, R., Cappa, C. D., Middlebrook, A. M., and Schwarz, J. P.: Brown carbon and internal mixing in biomass burning particles, P. Natl. Acad. Sci. USA, 109, 14802-14807, 2012.

Lan, Z. J., Huang, X. F., Yu, K. Y., Sun, T. L., Zeng, L. W., and $\mathrm{Hu}, \mathrm{M}$. : Light absorption of black carbon aerosol and its enhancement by mixing state in an urban atmosphere in South China, Atmos. Environ., 69, 118-123, https://doi.org/10.1016/j.atmosenv.2012.12.009, 2013.

Lelieveld, J., Evans, J. S., Fnais, M., Giannadaki, D., and Pozzer, A.: The contribution of outdoor air pollution sources to premature mortality on a global scale, Nature, 525, 367-371, https://doi.org/10.1038/nature15371, 2015.

Liu, D., Allan, J., Whitehead, J., Young, D., Flynn, M., Coe, H., McFiggans, G., Fleming, Z. L., and Bandy, B.: Ambient black carbon particle hygroscopic properties controlled by mixing state and composition, Atmos. Chem. Phys., 13, 2015-2029, https://doi.org/10.5194/acp-13-2015-2013, 2013.

Liu, D., Allan, J. D., Young, D. E., Coe, H., Beddows, D., Fleming, Z. L., Flynn, M. J., Gallagher, M. W., Harrison, R. M., Lee, J., Prevot, A. S. H., Taylor, J. W., Yin, J., Williams, P. I., and Zotter, P.: Size distribution, mixing state and source apportionment of black carbon aerosol in London during wintertime, Atmos. Chem. Phys., 14, 10061-10084, https://doi.org/10.5194/acp-1410061-2014, 2014.

Liu, D. T., Whitehead, J., Alfarra, M. R., Reyes-Villegas, E., Spracklen, D. V., Reddington, C. L., Kong, S. F., Williams, P. I., Ting, Y. C., Haslett, S., Taylor, J. W., Flynn, M. J., Morgan, W. T., McFiggans, G., Coe, H., and Allan, J. D.: Black-carbon absorption enhancement in the atmosphere determined by particle mixing state, Nat. Geosci., 10, 184-188, https://doi.org/10.1038/Ngeo2901, 2017.

Liu, Z. R., Hu, B., Ji, D. S., Wang, Y. H., Wang, M. X., and Wang, Y. S.: Diurnal and seasonal variation of the $\mathrm{PM}_{2.5}$ apparent particle density in Beijing, China, Atmos. Environ., 120, 328-338, https://doi.org/10.1016/j.atmosenv.2015.09.005, 2015.

Londahl, J., Pagels, J., Boman, C., Swietlicki, E., Massling, A., Rissler, J., Blomberg, A., Bohgard, M., and Sandstrom, T.: Deposition of biomass combustion aerosol particles in the human respiratory tract, Inhal. Toxicol., 20, 923-933, https://doi.org/10.1080/08958370802087124, 2008.

Malloy, Q. G. J., Nakao, S., Qi, L., Austin, R., Stothers, C., Hagino, H., and Cocker, D. R.: Real-Time Aerosol Density Determination 
Utilizing a Modified Scanning Mobility Particle SizerAerosol Particle Mass Analyzer System, Aerosol Sci. Technol., 43, 673678, https://doi.org/10.1080/02786820902832960, 2009.

Momenimovahed, A. and Olfert, J. S.: Effective Density and Volatility of Particles Emitted from Gasoline Direct Injection Vehicles and Implications for Particle Mass Measurement, Aerosol Sci. Technol., 49, 1051-1062, https://doi.org/10.1080/02786826.2015.1094181, 2015.

Moteki, N. and Kondo, Y.: Effects of mixing state on black carbon measurements by laser-induced incandescence, Aerosol Sci. Technol., 41, 398-417, https://doi.org/10.1080/02786820701199728, 2007.

Moteki, N., Kondo, Y., Oshima, N., Takegawa, N., Koike, M., Kita, K., Matsui, H., and Kajino, M.: Size dependence of wet removal of black carbon aerosols during transport from the boundary layer to the free troposphere, Geophys. Res. Lett., 39, L13802, https://doi.org/10.1029/2012g1052034, 2012.

Nakayama, T., Matsumi, Y., Sato, K., Imamura, T., Yamazaki, A., and Uchiyama, A.: Laboratory studies on optical properties of secondary organic aerosols generated during the photooxidation of toluene and the ozonolysis of alpha-pinene, J. Geophys. Res.Atmos., 115, D24204, https://doi.org/10.1029/2010jd014387, 2010.

Olfert, J. S. and Collings, N.: New method for particle mass classification - the Couette centrifugal particle mass analyzer, J. Aerosol Sci., 36, 1338-1352, https://doi.org/10.1016/j.jaerosci.2005.03.006, 2005.

Pagels, J., Khalizov, A. F., McMurry, P. H., and Zhang, R. Y.: Processing of Soot by Controlled Sulphuric Acid and Water Condensation Mass and Mobility Relationship, Aerosol Sci. Technol., 43, 629-640, https://doi.org/10.1080/02786820902810685, 2009.

Pan, X., Kanaya, Y., Taketani, F., Miyakawa, T., Inomata, S., Komazaki, Y., Tanimoto, H., Wang, Z., Uno, I., and Wang, Z.: Emission characteristics of refractory black carbon aerosols from fresh biomass burning: a perspective from laboratory experiments, Atmos. Chem. Phys., 17, 13001-13016, https://doi.org/10.5194/acp-17-13001-2017, 2017.

Pan, X., Ge, B., Wang, Z., Tian, Y., Liu, H., Wei, L., Yue, S., Uno, I., Kobayashi, H., Nishizawa, T., Shimizu, A., Fu, P., and Wang, Z.: Synergistic effect of water-soluble species and relative humidity on morphological changes in aerosol particles in the Beijing megacity during severe pollution episodes, Atmos. Chem. Phys., 19, 219-232, https://doi.org/10.5194/acp-19-219-2019, 2019.

Peng, J. F., Hu, M., Guo, S., Du, Z. F., Zheng, J., Shang, D. J., Zamora, M., Zeng, L. M., Shao, M., Wu, Y. S., Zheng, J., Wang, Y., Glen, C., Collins, D., Molina, M., and Zhang, R. Y.: Markedly enhanced absorption and direct radiative forcing of black carbon under polluted urban environments, P. Natl. Acad. Sci. USA, 252, 4266-4271, 2016.

Qiao, K., Wu, Z. J., Pei, X. Y., Liu, Q. Y., Shang, D. J., Zheng, J., Du, Z. F., Zhu, W. F., Wu, Y. S., Lou, S. R., Guo, S., Chan, C. K., Pathak, R. K., Hallquist, M., and Hu, M.: Size-resolved effective density of submicron particles during summertime in the rural atmosphere of Beijing, China, J. Environ. Sci.-China, 73, 69-77, https://doi.org/10.1016/j.jes.2018.01.012, 2018.

Qiu, C., Khalizov, A. F., Hogan, B., Petersen, E. L., and Zhang, R. Y.: High Sensitivity of Diesel Soot Morphological and Optical Properties to Combustion Temperature in a Shock Tube, Environ. Sci. Technol., 48, 6444-6452, https://doi.org/10.1021/es405589d, 2014.

Raaschou-Nielsen, O., Andersen, Z. J., Beelen, R., Samoli, E., Stafoggia, M., Weinmayr, G., Hoffmann, B., Fischer, P., Nieuwenhuijsen, M. J., Brunekreef, B., Xun, W. W., Katsouyanni, K., Dimakopoulou, K., Sommar, J., Forsberg, B., Modig, L., Oudin, A., Oftedal, B., Schwarze, P. E., Nafstad, P., De Faire, U., Pedersen, N. L., Ostenson, C. G., Fratiglioni, L., Penell, J., Korek, M., Pershagen, G., Eriksen, K. T., Sorensen, M., Tjonneland, A., Ellermann, T., Eeftens, M., Peeters, P. H., Meliefste, K., Wang, M., Bueno-de-Mesquita, B., Key, T. J., de Hoogh, K., Concin, H., Nagel, G., Vilier, A., Grioni, S., Krogh, V., Tsai, M. Y., Ricceri, F., Sacerdote, C., Galassi, C., Migliore, E., Ranzi, A., Cesaroni, G., Badaloni, C., Forastiere, F., Tamayo, I., Amiano, P., Dorronsoro, M., Trichopoulou, A., Bamia, C., Vineis, P., and Hoek, G.: Air pollution and lung cancer incidence in 17 European cohorts: prospective analyses from the European Study of Cohorts for Air Pollution Effects (ESCAPE), Lancet Oncol., 14, 813-822, https://doi.org/10.1016/s1470-2045(13)70279-1, 2013.

Ramanathan, V. and Carmichael, G.: Global and regional climate changes due to black carbon, Nat. Geosci., 36, 335-358, 2008.

Rissler, J., Nordin, E. Z., Eriksson, A. C., Nilsson, P. T., Frosch, M., Sporre, M. K., Wierzbicka, A., Svenningsson, B., Londahl, J., Messing, M. E., Sjogren, S., Hemmingsen, J. G., Loft, S., Pagels, J. H., and Swietlicki, E.: Effective Density and Mixing State of Aerosol Particles in a Near-Traffic Urban Environment, Environ. Sci. Technol., 48, 6300-6308, https://doi.org/10.1021/es5000353, 2014.

Schnaiter, M., Horvath, H., Mohler, O., Naumann, K. H., Saathoff, H., and Schock, O. W.: UV-VIS-NIR spectral optical properties of soot and soot-containing aerosols, J. Aerosol Sci., 34, 14211444, https://doi.org/10.1016/S0021-8502(03)00361-6, 2003.

Shiraiwa, M., Kondo, Y., Moteki, N., Takegawa, N., Sahu, L., Takami, A., Hatakeyama, S., Yonemura, S., and Blake, D.: Radiative impact of mixing state of black carbon aerosol in Asian outflow, J. Geophys. Res.-Atmos., 113, D24210, https://doi.org/10.1029/2008JD010546, 2008.

Shiraiwa, M., Kondo, Y., Iwamoto, T., and Kita, K.: Amplification of Light Absorption of Black Carbon by Organic Coating, Aerosol Sci. Technol., 44, 46-54, 2010.

Sun, Y. L., Wang, Z. F., Wild, O., Xu, W. Q., Chen, C., Fu, P. Q., Du, W., Zhou, L. B., Zhang, Q., Han, T. T., Wang, Q. Q., Pan, X. L., Zheng, H. T., Li, J., Guo, X. F., Liu, J. G., and Worsnop, D. R.: "APEC Blue": Secondary Aerosol Reductions from Emission Controls in Beijing, Sci. Rep.-Uk, 6, 20668, https://doi.org/10.1038/srep20668, 2016.

Tavakoli, F. and Olfert, J. S.: Determination of particle mass, effective density, mass-mobility exponent, and dynamic shape factor using an aerodynamic aerosol classifier and a differential mobility analyzer in tandem, J. Aerosol Sci., 75, 35-42, https://doi.org/10.1016/j.jaerosci.2014.04.010, 2014.

Taylor, J. W., Allan, J. D., Liu, D., Flynn, M., Weber, R., Zhang, X., Lefer, B. L., Grossberg, N., Flynn, J., and Coe, H.: Assessment of the sensitivity of core / shell parameters derived using the singleparticle soot photometer to density and refractive index, Atmos. Meas. Tech., 8, 1701-1718, https://doi.org/10.5194/amt-8-17012015, 2015. 
Toon, O. B., Pollack, J. B., and Khare, B. N.: OpticalConstants of Several Atmospheric Aerosol Species Ammonium-Sulfate, Aluminum-Oxide, and SodiumChloride, J. Geophys. Res.-Oc. Atm., 81, 5733-5748, https://doi.org/10.1029/JC081i033p05733, 1976.

Turpin, B. J. and Lim, H. J.: Species contributions to PM2.5 mass concentrations: Revisiting common assumptions for estimating organic mass, Aerosol Sci. Technol., 35, 602-610, https://doi.org/10.1080/02786820119445, 2001.

Wang, Q. Y., Huang, R. J., Cao, J. J., Han, Y. M., Wang, G. H., Li, G. H., Wang, Y. C., Dai, W. T., Zhang, R. J., and Zhou, Y. Q.: Mixing State of Black Carbon Aerosol in a Heavily Polluted Urban Area of China: Implications for Light Absorption Enhancement, Aerosol Sci. Technol., 48, 689-697, https://doi.org/10.1080/02786826.2014.917758, 2014.

Wang, Q. Y., Huang, R. J., Zhao, Z. Z., Cao, J. J., Ni, H. Y., Tie, X. X., Zhao, S. Y., Su, X. L., Han, Y. M., Shen, Z. X., Wang, Y. C., Zhang, N. N., Zhou, Y. Q., and Corbin, J. C.: Physicochemical characteristics of black carbon aerosol and its radiative impact in a polluted urban area of China, J. Geophys. Res.-Atmos., 121, 12505-12519, https://doi.org/10.1002/2016jd024748, 2016.

Wang, Y. Y., Liu, F. S., He, C. L., Bi, L., Cheng, T. H., Wang, Z. L., Zhang, H., Zhang, X. Y., Shi, Z. B., and Li, W. J.: Fractal Dimensions and Mixing Structures of Soot Particles during Atmospheric Processing, Environ. Sci. Tech. Let., 4, 487-493, https://doi.org/10.1021/acs.estlett.7b00418, 2017.

Wu, Y., Cheng, T. H., Liu, D. T., Allan, J. D., Zheng, L. J., and Chen, H.: Light Absorption Enhancement of Black Carbon Aerosol Constrained by Particle Morphology, Environ. Sci. Technol., 52, 6912-6919, https://doi.org/10.1021/acs.est.8b00636, 2018.

Wu, Y. F., Zhang, R. J., Tian, P., Tao, J., Hsu, S. C., Yan, P., Wang, Q. Y., Cao, J. J., Zhang, X. L., and Xia, X. G.: Effect of ambient humidity on the light absorption amplification of black carbon in Beijing during January 2013, Atmos. Environ., 124, 217-223, https://doi.org/10.1016/j.atmosenv.2015.04.041, 2016.
Wu, Y., Wang, X., Tao, J., Huang, R., Tian, P., Cao, J., Zhang, L., Ho, K.-F., Han, Z., and Zhang, R.: Size distribution and source of black carbon aerosol in urban Beijing during winter haze episodes, Atmos. Chem. Phys., 17, 7965-7975, https://doi.org/10.5194/acp-17-7965-2017, 2017.

Xue, H. X., Khalizov, A. F., Wang, L., Zheng, J., and Zhang, R. Y.: Effects of Coating of Dicarboxylic Acids on the Mass-Mobility Relationship of Soot Particles, Environ. Sci. Technol., 43, 27872792, https://doi.org/10.1021/es803287v, 2009.

Zhang, R. Y., Khalizov, A. F., Pagels, J., Zhang, D., Xue, H. X., and McMurry, P. H.: Variability in morphology, hygroscopicity, and optical properties of soot aerosols during atmospheric processing, P. Natl. Acad. Sci. USA, 105, 10291-10296, https://doi.org/10.1073/pnas.0804860105, 2008.

Zhang, Y., Zhang, Q., Cheng, Y., Su, H., Kecorius, S., Wang, Z., Wu, Z., Hu, M., Zhu, T., Wiedensohler, A., and He, K.: Measuring the morphology and density of internally mixed black carbon with SP2 and VTDMA: new insight into the absorption enhancement of black carbon in the atmosphere, Atmos. Meas. Tech., 9, 1833-1843, https://doi.org/10.5194/amt-9-1833-2016, 2016.

Zhang, Y. X., Su, H., Ma, N., Li, G., Kecorius, S., Wang, Z. B., Hu, M., Zhu, T., He, K. B., Wiedensohler, A., Zhang, Q., and Cheng, Y. F.: Sizing of Ambient Particles From a Single-Particle Soot Photometer Measurement to Retrieve Mixing State of Black Carbon at a Regional Site of the North China Plain, J. Geophys. Res.-Atmos., 123, 12778-12795, https://doi.org/10.1029/2018jd028810, 2018. 